Revista de Indias, 1997, vol. LVII, núm. 210

\title{
TRABAJADORES VASCOS EN EL RECUERDO POPULAR RIOPLATENSE ${ }^{1}$
}

\author{
POR
}

MARCELINO IRIANI

Universidad de Tandil, Argentina

\begin{abstract}
Se intentan dilucidar aspectos vinculados a ciertos estereotipos laborales de inmigrantes vascos en Argentina que perduran en el recuerdo popular, especialmente en lo que hace a la génesis de esas imágenes y el predominio de algunos oficios sobre otros. La conformación de los estereotipos (por ej. vasco lechero) no estaría directamente vinculado a un predomino cuantitativo de los vascos en esos oficios, sino también a ciertas características y aditamentos simbólicos vinculados a ellos. Para reconstruir la génesis del recuerdo popular sobre el mundo del trabajo decimonónico, se utilizan principalmente las cédulas censales correspondientes a los Censos Nacionales de 1869 y 1895, como asi también distintas fuentes literarias.
\end{abstract}

¿Quién no escuchó decir alguna vez que los inmigrantes vascos en Argentina eran lecheros, los italianos trabajadores 'golondrinas' y los turcos vendedores? Es comprensible que en su esfuerzo por entender el pasado la gente tienda a sintetizar procesos, como así también a fijar roles laborales a los distintos sujetos históricos. Igualmente llama la atención, a la hora de asociar inmigrantes y mercado laboral, la homogeneidad del recuerdo popular; máxime cuando se ha nutrido de fuentes diversas. Nos interesa, a través de estas páginas,

\footnotetext{
SIGLAS UTILIZADAS:

A.G.N.: Archivo General de la Nación, Argentina.

A.L.B.: Archivo Laurak Bat, Centro Vasco, Bs.As., Argentina.

1 Una versión preliminar fue presentada en las $V$ jornadas sobre colectividades, IDES, 26/27 de Octubre de 1995
} 
dilucidar aspectos vinculados a ciertos estereotipos ${ }^{2}$ laborales de los vascos, especialmente en lo que hace a la génesis de las imágenes y el predominio de algunos oficios sobre el resto. Según nuestra hipótesis, la conformación de los estereotipos no estaría siempre - ni únicamente - vinculado a un predominio cuantitativo de los vascos en ellos, sino a características y aditamentos simbólicos de esos oficios.

\section{LOS `FORJADORES' DEL RECUERDO}

Nuestra intención no es, cabe aclarar, juzgar la veracidad del recuerdo popular; muy por el contrario, nos interesa indagar las raíces de esas imágenes con el presentimiento de que puedan abrir nuevos caminos - en cuanto al uso de fuentes 'desprestigiadas' como las literarias- para la reconstrucción de las experiencias de los inmigrantes en Argentina.

¿Qué encierra, en este contexto, el concepto de recuerdo popular? Nos referimos, cuando hablamos de ello, a un abanico de manifestaciones - artísticas, literarias- y expresiones -discursos públicos, relatos personales- más o menos coincidentes acerca de un fenómeno social acontecido. Una característica sobresaliente es, sin duda, la falta de rigurosidad en el enfoque y tratamiento cualquiera sea el tema; por lo general, el recuerdo se manifiesta en forma atemporal e incluso sin una precisión geográfica. Pero el recuerdo popular también se caracteriza, entre otras cosas, por el hecho de no preservar la totalidad de los acontecimientos históricos; existe algún mecanismo, posiblemente inexplicable, que selecciona puntualmente algunos sucesos o fenómenos determinados. La inmigración, o más precisamente las tendencias ocupacionales de los distintos grupos de inmigrantes, parece ser uno de ellos. Luego de varios estudios parciales $^{3}$, los historiadores creemos saber cual habría sido el aporte por

2 Un trabajo que se acerca a lo que intentamos realizar es el de Jorge BESTENE: "Realidades y estereotipos: los 'turcos' en el teatro argentino" en Estudios Migratorios Latinoamericanos, n²6, 1994.

3 Posiblemente uno de los pioneros en estas observaciones haya sido Benito DIAZ: "Datos sobre la inmigración en la provincia de Buenos Aires (1820-1854)" en Humanidades, $\mathrm{n}^{\circ}$ XXXVI, Fac. de Human. y Cs. de la Educ., U.N.L.P., 1960; posteriormente Roberto CORTES CONDE: "Corrientes inmigratorias y surgimiento de la industria en Argentina, 1870-1914”, Bs. As., Fac. Fil. y Let., UBA, 1964; y El Progreso Argentino, Bs. As., ed. 
nacionalidades en cada sector de la producción e inclusive sobre ciertas preferencias ocupacionales de aquellos ${ }^{4}$. Curiosamente, los 'monopolios laborales' atribuidos ligeramente a los distintos grupos nacionales por el recuerdo popular no encuentran, en todos los casos, un sustento cuantitativo. El error surge, claramente, al comparar trabajos estadísticos con 'impresiones' atemporales que abarcan distintas regiones, cuando no provincias. Estamos convencidos, pese a ello, que aquellas impresiones contemporáneas fueron válidas y debieron tener razones importantes que las avalaron.

Una manera de abordar el fenómeno estriba en observar las fuentes que históricamente vincularon inmigrantes a determinadas actividades. Quizá la más importante sea el traspaso oral, por lo común propenso a las generalizaciones y síntesis ${ }^{5}$. Las memorias de viajeros también abundan en estereotipos ${ }^{6}$, a la vez que desdibujan regiones buscando simplificar lo observado. Algunos trabajos de autores contemporáneos ${ }^{7}$, al igual que los que reúnen historias de vi$\mathrm{da}^{8}$ también reflejan lo enunciado. Los periódicos ${ }^{9}$ (especialmente en

Sudamericana, 1979. Pero quienes lo han abordado más específicamente han sido Norberto AlvAREZ y Eduardo MigUEZ: "La estructura socio-ocupacional de Tandil, 1869 y 1895", Actas de las Cuartas Jornadas de Historia Económica, Córdoba, 1984 y Eduardo MiguEZ: "La movilidad social de nativos e inmigrantes en la frontera bonaerense en el s. XIX: datos, problemas, perspectivas" en Estudios Migratorios Latinoamericanos, n² 24, 1993.

4 Algunos trabajos específicos sobre grupos nacionales también han mostrado tendencias ocupacionales. Por ejemplo Hilda SABATO y Juan C. KOROL: ¿Cómo fue la inmigración irlandesa a la Argentina?, Bs.As., ed. Plus Ultra, 1981; también el de Liliana BERTONI: "De Turquía a Buenos Aires. Una colectividad nueva a fines del siglo XIX" en Estudios Migratorios Latinoamericanos, $\mathrm{n}^{\circ}$ 26, 1994.

5 Esto pude comprobarlo en las entrevistas realizadas a vascos de principios de siglo y descendientes a propósito de un trabajo sobre hotelería vasca. Ver Marcelino IRIANI: "Cómo en nuestra casa'...Fondas y hoteles vascos en Tandil, 1860/1940" en Siglo XIX, n 16, México, Instituto Mora, 1994.

6 El viajero inglés MACCann es un buen modelo de lo que queremos expresar. En sus memorias los irlandeses y vascos son zanjeadores y pastores, los nativos realizan únicamente tareas ecuestres, etcétera. W. MACCANN: Viaje a caballo por las provincias argentinas, Bs. As., ed. Hyspamérica, 1987.

7 Para la zona de Tandil Ramón GorRaIz BeloQui: Tandil a través de un siglo, 1823/1923, Bs.As., Tall. Matera, 1958; Osvaldo FonTANA: Tandil en la historia, Imp. Vitullo, 1947; y E. DELPECH: Memorias de una vida en la Argentina, Bs. As., ed. Peusser, 1944; para Lobería, José M. SUAREZ GARCIA: Historia del partido de Lobería (2 tomos), Bs.As., 1940: para Chascomús: Rolando DoNCASBERRo: Chascomús, 1931.

8 Para una síntesis de los vascos que alcanzaron progresos - muchos en los oficios en cuestión- ver José URIARTE: Los baskos en la nación Argentina, Bs.As., Tall. de La 
sus aniversarios), y algunas revistas ${ }^{10}$ muestran con frecuencia caricaturas alusivas a estos oficios. El Cine ${ }^{11}$ y el Teatro ${ }^{12}$, fenómenos de comunicación masivos ${ }^{13}$, también han transmitido estereotipos a los concurrentes a sus salas. Por último, es indudable que el recuerdo popular se construye, en buena parte, durante la educación escolar primaria; acaso por ser el escalón mínimo alcanzado por una mayoría. Allí, los inmigrantes aparecen didácticamente asociados a ciertos oficios o costumbres, ya sea en los actos patrios ${ }^{14}$ como en los libros de lectura. Sabido es que dentro de los objetivos básicos de la etapa de educación primaria se encuentra - junto a la socialización- el de la formación de una identidad nacional. Aunque no sea este el momento para examinar el tema, vale recordar que los contenidos de dicho aprendizaje 'sintetizan' - simplificando roles, generalmente ejemplificadores - obligadamente los sujetos históricos de nuestro pasado a un puñado de personajes. Así cobran importancia, en primer lugar, los próceres (civiles, militares, caudillos provinciales, etc.) y como símbolo nacional, el gaucho. Luego - y en un peldaño superior a los aborígenes locales e incluso a los migrantes internos- se encuentran los inmigrantes, a los que se les atribuye el haber poblado y 'civilizado' estos espacios vacíos y bárbaros. Los

Baskonia, 1919. Para el caso tandilense Lidio SAGLUL (compil.): ¿Quién fue y quién es quién en nuestra ciudad?, Tandil, 1955.

9 En Tandil lo observamos en las publicaciones de los Veinticinco y Cincuenta aniversario del diario NUEVA ERA, como así también en el Centenario de EL ECO. Lo mismo se observa en la publicación de el centenario de Necochea en el Ecos Diario, 1985.

10 Acaso las más notables sean Caras y Caretas y Fray Mocho; con otro estilo y objetivo Vida Agraria también sintetiza oficios y nacionalidades. Para el caso específico vasco, La Baskonia es el ejemplo más claro.

11 Aunque no hemos encontrado muchos casos de películas con protagonistas vascos en suelo argentino al estilo de Mientras nos dure la vida (que relata las peripecias de una familia de tamberos vascos, 1920), en la mayoría de las películas cuyo escenario es el campo, pueden verse vascos ligados a la lechería, alambrados o carretas.

12 Para ampliar sobre el teatro en la conformación de imágenes (especialmente la de los 'turcos'), ver el trabajo de BESTENE [2].

13 Existen otros mecanismos de comunicación gráfica que indudablemente han influenciado en el recuerdo. Un buen ejemplo, por la popularidad y la difusión que tuvo, refiere a los famosos almanaques de Molina Ocampo ("ALPARGATAS") que plasmó en sus cuadros todo el espectro de personajes -entre los que hay inmigrantes- ligados al agro.

14 Recientemente, en el acto conmemorativo de la Independencia Argentina (25 de Mayo de 1810), los alumnos de la Escuela ${ }^{\circ} 34$ (Tandil) representaron imágenes de época. Los lecheros - 30 años antes de que llegaran los primeros inmigrantes- evocaban la figura de vascos.

R. I., $1997, \mathrm{n}^{\circ} 210$ 
libros utilizados en la educación primaria también han estereotipado, con frecuencia, al inmigrante; trabajadores titánicos, desinteresados por la política y que dedicaron su vida a una tierra que no era la de ellos, son algunos de los rasgos sobresalientes -en buena parte ciertos- de aquellos trabajadores extranjeros. De todos modos, al tiempo que se delineaba el perfil agroexportador de la Argentina, los distintos grupos nacionales comenzaron a ocupar un espacio histórico -más o menos relevante- en la conformación del país. Mientras el gaucho fue recuperado de los tiempos como jinete y ligado a tareas pecuarias (principalmente vacunos y equinos); los inmigrantes lo hicieron como labradores y en diversas tareas —en contraposición al gaucho- de 'a pié. Como veremos a lo largo del trabajo, los españoles y en parte los italianos y franceses, quedaron mayormente plasmados en la memoria con sus aportes a oficios urbanos. Los vascos, daneses, franceses, ingleses e irlandeses asociados a tareas agrarias y pastoreo ovino. Mientras que la zona intermedia, entre el campo y la ciudad - junto a los almaceneros vascos-, fue claramente 'monopolizada' por la imagen de los chacareros y quinteros italianos. ${ }^{15}$

Ahora bien, la mayoría de los 'responsables' de estas fuentes debieron desconocer el espectro de actividades en que se emplearon los vascos u otros inmigrantes; sin embargo tuvieron una SENSACIÓN de predominio de unas tareas sobre otras; tal impresión es la que nos interesa recuperar. Queda por dilucidar, y no es poco importante, si estas fuentes intentaron reflejar una tendencia dentro del universo de cada grupo nacional o, por el contrario, comparaban con el resto de los inmigrantes. Resulta difícil generalizar acerca de los posibles objetivos - conscientes o no- de cada fuente. La mayoría, según se desprende de la lectura, parece haber observado tendencias de cada colectividad. Una excepción fue el caso de las 'imágenes' pergeniadas por los sectores altos; precisamente por que intentaban contrastar aportes de los distintos inmigrantes. De todos modos, si nuestra línea argumental es correcta, los mismos elementos que colaboraron para asociar ciertas actividades como vascas - por ejem-

15 Esto no significa que no hubiese, como de hecho encontramos en nuestros estudios, españoles e italianos agricultores, daneses o vascos en tareas urbanas, etcétera. Otra excepción deviene del oficio de lechero de los vascos, y luego italianos. Precisamente, es esa síntesis poco rigurosa que se conformó en el recuerdo popular la que intentamos reconstruir. 
plo la vestimenta típica ${ }^{16}$ - pesarían a favor de un predominio visual comparado con otros grupos. El recuerdo de los vascos lecheros, los turcos vendedores o los italianos golondrinas, nos hacen pensar que a los contemporáneos no les resultaban indiferentes aquellos oficios que, ya por su importancia, su movilidad o elementos adicionales, se destacaban del resto. Precisamente, un elemento común de las tareas que han perdurado es su carácter 'público'. El lechero, por ejemplo, era un personaje socialmente distinguido. Recorría diariamente los caminos vecinales desde el tambo e inclusive las calles del pueblo, lo que sumado a la particularidad de los utensilios portados (grandes tarros) y la singular vestimenta de los vascos (boina, faja y alparga$\operatorname{tas}^{17}$ ) lo convertían en un elemento del paisaje entre fines del siglo pasado y principios de éste. No podía pasar desapercibido, “..antes de que llamase a las puertas, las vecinas ya sabían que llegaba el lechero. En efecto, venía el basko alborotando.. Recorría la ciudad, puerta tras puerta.. Después que terminaba su tarea, el lechero se iba a jugar a la pelota, a comer con sus amigotes y a beber más de lo debido.."18 Es esperable, por lo tanto, que en los recuerdos de los contemporáneos este oficio ocupase un lugar especial; no sucedería lo mismo, por comparación, con los zapateros, hojalateros, carpinteros, domésticos y otros oficios 'de puertas adentro'.

Pero había aún más elementos que les destacaban. En Chascomús y Tandil hubo, hacia 1869, varias decenas de vascos horneros; luego, hacia fines de siglo los italianos debieron predominar en el oficio del barro en varios pueblos ${ }^{19}$, pero la coyuntura temprana - déficit habi-

16 "El campo de la provincia de Buenos Aires no está poblado sólamente de gauchos; hay también un número considerable de europeos...No tardan éstos últimos en adoptar la forma de vida de los gauchos y una parte de su indumentaria; sin embargo, CONSERVAN SIEMPRE ALGÚN DETALLE DE SU MODO DE VESTIR NACIONAL Y, SOBRE TODO LOS VASCOS, POCAS VECES RENUNCIAN A SU BOINA TRADICIONAL". H. ARMAIGNAC: Viaje por las pampas argentinas, 1869/1874, Bs.As, 1976.

17 Con el paso del tiempo los trabajadores nativos - no siempre descendientes de aquellos - adoptaron masivamente la indumentaria vasca, dejando chiripás, pesados cintos, botas y chambergo. Esto debió sobredimensionar la imagen de colectividad vasca, como así también su participación en los distintos oficios.

18 José M. SALAVERRIA:"La acción de los baskos en el progreso argentino" en José R. URIARTE: Los baskos en el centenario, Bs. As., ed. La Baskonia, 1910, pp. 21/22.

19 "Durante las primeras décadas de la segunda mitad del siglo XIX, los vascos eran mayoría entre los obreros ladrilleros. Después serán suplantados en esa posición por los trabajadores italianos". Boletín del Departamento Nacional de Trabajo, $\mathrm{n}^{\circ} 4$, Marzo, 1908, p. 27, citado en Ricardo FALCON: "Inmigración, cuestión étnica y movimiento obrero 
tacional y formación de pueblos- en que se instaló el ladrillo vasco le brindó la posibilidad de perdurar en el tiempo. Este sencillo ejemplo nos alerta acerca de la importancia - relativa a la época y lugar- del oficio o sus productos como parte de la explicación. Pensemos en los lácteos, en pleno crecimiento de la población y diversificación de la dieta tradicional - que los propios inmigrantes ampliaban - y cuando la leche suplantaba en muchas zonas al agua, temible portadora de pestes. En ese mismo sentido encuentran su justificación los alambradores y poceros, lo mismo que los pastores (portadores del conocimiento sobre una producción alternativa). Así, los escasos zanjeadores vascos de Chascomús o Lobería -realizando tareas titánicas o largamente esperadas ${ }^{20}$ por el pueblo- pudieron llamar más la atención que sus numerosos paisanos zapateros y carpinteros. Pero un oficio también podía atraer miradas por sus características y hasta por el empleo de los ratos de ocio de sus ejecutores. Nos referimos a la práctica de deportes extralaborales ${ }^{21}$, fenómeno especialmente llamativo ${ }^{22}$ para la época; al carácter rudo ${ }^{23}$ y el esfuer$\mathrm{zo}^{24}$ que demandaba, e inclusive por simples anécdotas ${ }^{25}$-comentario del vecindario y los viajeros. Todo ello motivaría distintas acti-

(1870-1914)" en F. Devoto y E. MigueZ (compil.): Asociacionismo, trabajo e identidad étnica, Bs.As, CEMLA/IEHS, 1992.

20 Nos referimos desde zanjeados para nuevas fortalezas contra los indios hasta aguadas y pozos de molinos para dar de beber a la gente y los animales.

21 "En los saladeros el inmigrante se encontraba en un entorno enteramente vasco. El traje vasco del viejo Mundo, con su boina, fajín rojo y alpargatas estaba a la orden del día. La mayoría de los saladeros contaban con un frontón de pelota vasca donde los trabajadores jugaban en sus horas de ocio" F.H. LESCA: Les basques et les bearnais dans l'Argentine el l'Uruguay, Bordeaux, 1907. El juego de pelota era común también, como vimos, entre los lecheros.

22 "Los vascos habían introducido algunas canchas de pelota en la década de 1850, pero éste seguía siendo un deporte de extranjeros locos" James ScoBIE: Buenos Aires. Del centro a los barrios, 1870/1910, Bs.As., ed. Solar, 1977, p.69.

${ }^{23}$ El recuerdo dice que "los vascos organizaron sus tambos amansando vacas a golpes de puño". Horacio GIBERTI: Historia económica de la ganadería argentina, Bs.As., ed. Solar, 1981, p.p. 190/92.

24 "Los trabajadores vascos fueron grandes alambradores. La dura tarea de cavar hoyos en el suelo y de clavar pesados postes...la penosa labor de extender y estirar hilos de alambre por miles de leguas, requería brazos potentes, manos poderosas y voluntades perseverantes.."José M. GARCIARENA: Viejas cartas de tierra adentro, Bs.As., ed. EKIN, 1977, p. 160.

${ }_{25}$ En 1867, unos poceros vascos de Necochea mantuvieron 'a raya' a un pequeño malón de indios arrojándoles piedras durante varias horas desde los pozos de jaguel que realizaban. Ecos diario. Centenario, Necochea, 1985, p. 23. 
tudes de los estratos sociales nativos hacia los inmigrantes; y ésto incidiría a su vez en la selectiva memoria popular. Si observamos a quienes contaban con mayores posibilidades de expresión pública, o sea los estratos altos, veremos que la actitud varió - respecto a los españoles - desde una hispanofobia posindependentista hasta una hispanofilia en el centenario patrio ${ }^{26}$."No todos los hijos de la Madre Patria eran iguales..los españoles eran divididos en Quijotes y Sancho Panzas. Surgió toda una mitología sobre los hidalgos castellanos y vascos, que para la mentalidad romántica y nostálgica de la élite literaria representaban el alma misma de la Argentina pastoral, patricia y patriarcal. Esta era la sangre de los gloriosos conquistadores que habían edificado la nobleza fundamental del país y de su clase dirigente, y la SANGRE DE LA HERCULEA RAZA VASCA, que había dominado las pampas y revitalizado a dicha clase. La otra cara de este mito era el sirviente gallego, el Sancho Panza.."27 Al momento de reconocer aportes a la inmigración las plumas nativas podían ennoblecer o desmerecer con asociaciones a distintos oficios ${ }^{28}$. Los vascos, por lo común, suelen estar ligados a oficios rudos, sin éxitos rotundos, dependientes de un esfuerzo propio generalmente FAMILIAR; también siempre dispuestos a arraigarse. Distintos parecen ser - aunque recordemos que se trata de estereotipos dudosamente representativos- el caso del comerciante gallego, el vendedor ambulante turco o el golondrina italiano ligeramente asociados a la ganancia fácil, más a HACERSE LA AMERICA que contribuir al desarrollo del país. Desde 1850 en adelante la sociedad podía percibir también claras señales - desde discursos políticos hasta avisos periodísticos - sobre la importancia de atraer inmigración más apta para poblar el desierto argentino y ocuparse de ciertas tareas. Inclusive "era común ver en los anuncios de los diarios que demandaban

\footnotetext{
26 José C. MoYA: "Parientes y extraños: actitudes hacia los inmigrantes españoles en la Argentina en el siglo XIX y comienzos del s. XX" en Estudios Migratorios Latinoamericanos, $\mathrm{n}^{\circ} 13$, Bs.As., 1989.

${ }^{27}$ Ibidem, p. 517.

${ }^{28}$ Las imágenes no se plasmaban únicamente en libros y provenientes de los sectores altos. Según Jorge BESTENE [2] las obras de teatro de las primeras décadas de este siglo eran escritas por sectores medios, generalmente hijos de inmigrantes. En su caso de estudio, "los autores muestran a los turcos dedicados fundamentalmente al trabajo (como comerciantes) con una gran ansiedad que se convierte en uno de los temas centrales de sus vidas. Para los autores los inmigrantes vinieron solamente a "hacer la América", ignorando las causas no económicas que para este grupo fueron también importantes como motivo de emigración".
} 
mano de obra, avisos del siguiente tenor: `Ama de leche italiana. Se necesita. $\mathrm{O}$ agricultor vasco'. Este mecanismo de prestigio que suponía ya una identificación previa entre grupo étnico y oficio, terminaba realimentándola" 29 En síntesis, la conformación de las imágenes remite a una variada cantidad de fuentes; las mismas provenían de distintos estratos - ocultando posturas ideológicas- y solían estar viciadas por observaciones subjetivas, preestadísticas y que ponderaban lo cualitativo sobre lo cuantitativo.

Respecto al predominio de imágenes masculinas, creemos que los porcentajes a favor de ese sexo en el flujo inmigratorio sumado a un mayor número de tareas que demandaban hombres, opacaron la participación femenina en la conformación de la Argentina actual. Sin embargo, algunas fuentes reconocen parte del éxito de la inserción vasca - en el caso de los pastores, lecheros u hoteleros- en el ofrecimiento laboral del grupo familiar, donde la mujer cumplía un rol tan importante como su marido. Más tardíamente, y en ámbitos urbanos, se plasmaron algunos estereotipos laborales ligados a mujeres inmigrantes: por ejemplo las amas de leche italianas, las prostitutas francesas y las dependientes "gallegas"30.

\section{IMÁGENES QUE LLEGAN DESDE EL PASADO}

"Zanjeador, alambrador o lechero, consigo siempre trae el basko la fuerza poco común que le diera su vida fatigosa de montañés..."

GODOFREDO DAIREAUX ${ }^{31}$

Los vascos, pese a su inferioridad numérica frente a italianos y españoles, han logrado un lugar privilegiado dentro de la historia argentina. Las razones más simples acaso se hallen en un arribo temprano y su asociación al poblamiento real de la frontera y las

29 FALCON [27] p. 255.

30 La difusión más clara de la relación 'gallegos' / servidumbre se refleja en RAMONA, personaje de una popular historieta cómica de la década del '30, así como en las primeras películas de Niní Marshall (p. ej. CANDIDA, 1937). Ver MoYA [24]

31 Godofredo DAIREAUX: "Conquistadores pacíficos" en URIARTE [17]. 
tareas pecuarias ${ }^{32}$. En la imagen que esbozan nuestros abuelos sobresalen el carácter rudo de sus tareas y la honradez, y cuando hay que asociarlos a ciertos oficios los de lechero, carrero, alambrador y pocero. ¿Cuánto hay de cierto en ésto? Si los vascos se emplearon en un abanico amplio de actividades ${ }^{33}$, ¿porqué se asocian mayormente a determinadas tareas?

Pensábamos, en un primer momento, que para rastrear el origen de las imágenes resultaba imprescindible acotar los marcos temporal y espacial. No tenía sentido buscar la génesis de la asociación 'pastores vascos' fuera de la zona ovina - aunque también los hubo, ni de la etapa de auge de esa producción. Tampoco rastrear vascos alambradores antes de 1875/80 ni fuera de la pampa húmeda. Pero mucho menos buscar aquellas imágenes, o sus responsables, lejos de zonas donde se asentaron grupos importantes de euskaldunes. De allí nuestro amplio criterio al elegir el período y las zonas representativas de los oficios en cuestión ${ }^{34}$.

Chascomús debió configurar un punto representativo, en distintos momentos, en cuanto a las producciones ovina y láctea; mientras que en Tandil y Lobería debió ser frecuente encontrar a numerosos lecheros y ganaderos en general. En ambas zonas, por ser pueblos nuevos, también factible encontrar zanjeadores, carreros y ladrilleros y toda una gama de oficios propios de asentamientos en formación como herreros, carpinteros, albañiles, panaderos y zapateros. Para encontrar alguna explicación a las asociaciones teníamos que ver, forzosamente, si también había vascos empleados en ocupaciones que el recuerdo ha olvidado o asociado a otro grupo nacional. En aquellos sitios, por último, los euskaldunes conformaron agrupaciones considerables durante todo el siglo XIX.

32 "Así como los inmigrantes italianos y en parte españoles fueron esencialmente agricultores, los vascos se dedicaron a la ganadería." Baskonia, Anuario Vasco argentino, Bs. As., 1956.

33 Marcelino IRIANI: "Los vascos y la inmigración temprana en la provincia de Buenos Aires. Su inserción en la estructura productiva, 1840/1880", en Estudios Migratorios Latinoamericanos, $\mathrm{n}^{\circ} 20$, Bs.As., 1992.

34 Aunque nuestra investigación es más amplia y se ocupa de la totalidad de los oficios u ocupaciones asignados a los vascos (lecheros, peones de saladeros, pastores, zanjeadores, ladrilleros, ganaderos y hoteleros), en este artículo, por razones de espacio, sólo ofreceremos el desarrollo de algunos de ellos.

R. I., $1997, \mathrm{n}^{\circ} 210$ 
CUADro 1 - APORTE POBLACIONAL VASCO. PORCENTAJES, 1869/1895

\begin{tabular}{lcccccc}
\hline Partido & 1869 & Tot. Pobl. & $\%$ & 1895 & Tot. Pobl. & $\%$ \\
\hline Chascomús & 960 & 9637 & 9,96 & 914 & 13044 & 7,00 \\
Tandil & 266 & 4870 & 5,46 & 760 & 14982 & 5,07 \\
Lobería & 101 & 2901 & 3,48 & 507 & 8480 & 5,97 \\
\hline
\end{tabular}

Fuente: CÉDULAS CENSALES, PRIMER Y SEGUNDO CENSO NACIONAL, 1869 y 1895, AGN.

En cuanto al marco temporal, creemos que ambos Censos Nacionales (1869 y 1895)- señalan momentos claves para la conformación de las imágenes que rastreamos. Sin embargo, a medida que analizábamos las fuentes, comenzamos a cuestionar la importancia $-\mathrm{y}$ la posibilidad real- de una comprobación cuantitativa a la vez que geográficamente acotada. Confeccionar un cuadro general de la provincia por oficios y nacionalidades resulta menos que impensable; máxime cuando los vascos se ocultan tras españoles y franceses. Ninguna de las imágenes ${ }^{35}$ debió conformarse - salvo contadas excepciones- a partir de un pueblo o partido sino de zonas más extensas; por otra parte, no debió tratarse de momentos concretos sino de procesos. También es posible que - tal lo que sucede con los poceros vascos en la pampa - ciertas imágenes cobraran fuerza ante la ausencia - y no la abundancia - de trabajadores. Pese a estas limitaciones, una observación de las cédulas censales ${ }^{36}$ —complementada con fuentes literarias-, debería permitirnos constatar algunos aspectos del fenómeno. Entre otras cosas, el aporte de estas regiones a los estereotipos en dos momentos distintos.

35 Una excepción parece ser la imagen de los peones vascos en los saladeros, mayormente buscados por su fortaleza. Estos establecimientos estaban geográficamente agrupados en el sur de la ciudad de Buenos Aires. Lo mismo sucedería con los montenegrinos en el Tandil finisecular, ligados a los trabajos de la piedra.

36 Respecto a las cédulas censales se debe tener ciertas precauciones. Sabemos, por ejemplo, que el oficio que declaraba cada trabajador no siempre reflejaba lo que realizaba. Respecto al caso vasco conoceremos la cantidad - no siempre discriminada entre patrones y empleados - de trabajadores en el rubro lechería, en los hornos de ladrillo y transporte; pero tendremos inconvenientes en cuanto al comercio y la producción ganadera, como así también en aquellos oficios que aparecen ligados a los jornaleros: poceros, zanjeadores y alambradores. 


\section{A MODO DE EJEMPLO: LOS VASCOS LECHEROS}

Pocos ejemplos tan ilustrativos respecto a nuestro problema a investigar que la figura - tantas veces repetida y tantas menos sustentada - que la de los vascos lecheros. ¿Qué hubo de cierto en ésto? Hagamos un esfuerzo para imaginar el mundo laboral que verían a diario los vecinos -y ocasionales viajeros- del Chascomús decimonónico. En los campos y chacras cercanas, y si corrían los años 1850 a 1870, no sería demasiado difícil - dadas sus características y atuendos típicos - ver a los euskaldunes que se ocupaban como pastores. Allí predominaban, de todos modos, los vascos empleados como peones y jornaleros; y aquello sí -debido a que realizaban actividades estacionales diversas - era más difícil de visualizar, o al menos de retener en la memoria asociándolos a una ocupación.

Cuadro 2 - Trabajadores Vasco. Chascomus, 1869

\begin{tabular}{lrlrlr}
\hline OFICIO & n. $^{\circ}$ & OFICIO & n. $^{\circ}$ & OFICIO & n. $^{{ }^{0}}$ \\
\hline Albañil & 12 & Ferroviario & 2 & P/saladero & 35 \\
P/albañil & 1 & hecendado & 18 & Propietario & 1 \\
Arrendatario & 4 & Herrero & 5 & Puestero & 5 \\
Capataz & 1 & Hornero & 24 & Quintero & 5 \\
Carnicero & 1 & P/hornero & 24 & P/quintero & 2 \\
Carrero & 33 & Jornalero & 71 & Sirvienta & 30 \\
P/Carrero & 1 & Labrador & 31 & Tropero & 2 \\
Carpintero & 29 & Lavandera & 7 & Tonelero & 1 \\
Cocinero & 14 & Lechero & 3 & Trabajador & 12 \\
Comerciante & 57 & Medianero & 16 & Zanjeador & 4 \\
Costurera & 8 & Panadero & 14 & Zapatero & 18 \\
Dependiente & 19 & Pastores & 80 & & \\
Doméstica & 1 & Planchadora & 3 & & \\
Entanciero & 2 & Peón & 116 & & \\
\hline
\end{tabular}

Fuente: CÉDULAS CENSALES, PRIMER CENSO NACIONAL, 1869, Sala X, A.G.N.

Respecto a los oficios comúnmente asociados a los vascos en el recuerdo popular, los datos censales confirman que había 80 pastores; 48 horneros; 34 carreros y 4 zanjeadores vascos.(ver cuadro 2)

R. I., $1997, \mathrm{n}^{\circ} 210$ 
Estas cifras parecen, a primera vista, apuntalar una conformación cuantitativa de las imágenes en cuestión; pero una mirada más detenida del cuadro nos muestra que los vascos se repartían por igual entre el campo y la ciudad. Había también 57 comerciantes, 31 labradores, 29 carpinteros, 18 zapateros y 14 panaderos euskaldunes que no consiguieron - aunque sólo se desprendieran de sus boinas y fajines para dormir - un lugar en el recuerdo. Todo parece indicar que la movilidad espacial propia de los lecheros, zanjeadores, alambradores y carreteros, pero no de los zapateros, herreros y carpinteros, debió jugar sus cartas en el asunto. En otros oficios no era el trabajador quien tenía movilidad espacial sino sus productos; tal lo que parece haber sucedido con los gigantescos $-\mathrm{y}$ aún recordados - ladrillos vascos.

De todos modos, la cantidad de trabajadores en un oficio - como así también la frecuencia-, no debieron ser menos importantes. En el cuadro 2 se aprecian, de alguna manera, las dimensiones geográfico-temporal que debieron tener en sus comienzos las asociaciones laborales. Mientras en 1869 Chascomús aportó a las imágenes de los vascos pastores y en menor medida de los horneros, carreros y zanjeadores, no debió suceder lo mismo con los lecheros, dado que sólo contaba con 3 casos. Cuando finalizaba el siglo, tres décadas más $\operatorname{tarde}^{37}$, los lecheros y tamberos sumaban 61 , los carreros sólo 2 y 13 los pastores. (ver cuadro 3 )

La figura del lechero vasco, al parecer, hacía tiempo que venía gestándose, desbordando los límites de un pueblo o un partido; comprendiendo lugares tan cosmopolitas como la capital, donde pronto opacó otros oficios característicos de los euskaldunes ${ }^{38}$.

"Regresando (en 1895) de un baile en una quinta de Flores y resolviendo esperar el primer tranvía de la mañana me metí en la única casa

\footnotetext{
37 Entonces, 815 vascos vivían en Chascomús; 488 eran vasco-peninsulares y 327 vasco-franceses; 571 pertenecían al sexo masculino y 239 al femenino. La comunidad vasco-argentina alcanzaba la cifra nada desapercibida de 2264 personas. Cédulas censales, segundo censo nacional, 1895, Sala X, AGN.

38 "Lo que era Buenos Aires en aquellos tiempos (mitad del XIX). La colonia vasca era numerosa por entonces y aunque por lo general nuestros paisanos prefirieron salir al campo, hubo un núcleo que quedó en la ciudad. Casi todos eran artesanos, en su mayoría del Norte del Pirineo... Predominaban los zapateros, pero también había quienes empezaban a dedicarse al oficio que luego fue característico de los vascos de Buenos Aires, el de LECHEROS." GaRCIARENA [22]
} 
de negocio que encontré abierta en Rivadavia al 6900. El pequeño negocio consiste en un almacén con marcado aspecto de pulpería y pertenece a un matrimonio euskalduna, vasco francés el marido y vizcaína la esposa. A las cuatro de la mañana aproximadamente empezó a llegar una legión de lecheros, la mayoría vascos, conté durante las dos horas que permanecí allí, 187."39

No es necesario un gran esfuerzo para imaginar el efecto que produciría, en el almacenamiento de los recuerdos, más de un centenar de lecheros vascos 'agrupados'. Igual efecto tendrían varias decenas de lecheros vascos deambulando por las callejuelas de la Gran Aldea, sobre todo a partir de sus 'innovaciones'. En efecto, "hacia 1875 los lecheros vascos habían introducido el carrito de reparto, el cual tenía acoplado a las ruedas un ingenioso mecanismo que, impulsado por ellas, batía la crema y la transformaba en manteca durante el recorrido. Hasta ese momento, la manera de hacerlo había sido el 'tambo ambulante'; la venta de la leche fluida al pié de la vaca, mediante el arreo del animal por toda la ciudad y su ordeño a pedido de los consumidores en cada casa"40.

Luego el estereotipo se fortaleció en la zona que va desde La Plata hasta chascomús, englobando a Cañuelas, San Vicente ${ }^{41}$ y otros pueblos. Según se desprende de las fuentes $-y$ apuntalando nuestra idea de la movilidad-, el lechero contribuyó mayormente al recuerdo que el tambero, aunque se trató de actividades en un principio realizadas por la misma persona o familia. Ya en este siglo, la figura del lechero aparecería desvinculada de la producción; primero repartiendo para algún tambero cercano ${ }^{42}$ pero lenta e irreversiblemente

39 Luis JAIZKIBEL: "Sección Amena" en La Vasconia nº 55, Bs.As., 1895.

40 Roberto Ferrero y F. CRAvero: "El descubrimiento de la buena leche. Los comienzos de la industria lechera argentina" en Todo es Historia, $\mathrm{n}^{\circ}$ 196, Bs. As., Septiembre de 1983, p. 34.

41 Ya en este siglo - posiblemente por la suma de lecheros en cada pueblo- se justificó la publicación de una revista, Esnea (leche en euskera) Los primeros números aparecen en 1914. El contenido básico refiere a cuestiones sobre la producción y comercialización láctea entre los productores vascos de la zona mencionada. A.L.B., Bs. As.

42 Los lecheros de la capital.."esperaban a pocos metros de la estación de Constitución los tarros de leche enviados por los tamberos (en su mayoría vascos) por tren desde la zona de Cañuelas, San Vicente y otros puntos. El lugar de reunión solía ser -como en nuestro caso- un hotel cuyo propietario era vasco y donde alrededor del día diez de cada mes acudían los tamberos para cobrar por la cantidad de tarros enviados". Entrevista al Sr. Eduardo Auzmendi, descendiente del propietario del Hotel Euskalduna en Constitución, Tandil, Diciembre de 1993.

R. I., $1997, \mathrm{n}^{\circ} 210$ 
cayendo bajo el monopolio de los -más higiénicos ${ }^{43}$ y baratosproductos de la fábrica. Los vascos fueron, en realidad, tamberos que durante parte del período repartieron su producción. Probablemente ambas actividades se ocultaran con frecuencia en otros oficios; el primero dentro de los labradores, agricultores o quinteros siendo el ordeñe una actividad complementaria - y el segundo trás los jornaleros y peones. Nuestra duda se apoya en el escaso número de lecheros y tamberos detectados en los distintos puntos, pero principalmente en las cercanías de la capital. En Barracas al Norte encontramos -entre 1855 y 1869 - un sólo lechero vasco; mientras que en Barracas al Sur - hacia 1869- 14 vascos declararon ser lecheros pero ninguno tambero. ${ }^{44} \mathrm{En}$ ambos lugares comprobamos, una vez más, que las cifras mencionadas se pierden entre otras mayores de comerciantes, panaderos, carpinteros y zapateros.

Pero habíamos adelantado que el fenómeno de las asociaciones laborales debió estar mayormente ligada a procesos. La lechería —en la creencia de muchos, históricamente vasca-, estuvo durante parte del siglo XIX compartida con otros grupos nacionales. Las preferencias ocupacionales que comenzaron a perfilarse en el último cuarto del siglo pasado, como también coyunturas políticas y económicas cambiantes 'reordenaron' los destinos de los distintos grupos nacionales. Según el profesor Panettieri ${ }^{45}$, hasta la época de Rosas los lecheros eran hombres, mujeres y niños del país. Las guerras civiles y las consiguientes levas alejaron a los hombres de este oficio, quedando en manos de las mujeres y niños de 8 a 10 años. Luego comenzaron a venir los vascos, quienes con su característica vestimenta y su forma de ser se distinguían notablemente del resto de la población" 46 . También se cree que "en la década del ` 50 ingleses e irlandeses se volcaron de lleno a la producción ovina, los nativos conti-

\footnotetext{
43 "La mayoría de los alimentos se vendían en deplorables condiciones de higiene y la leche no podía ser la excepción; era traída a caballo en 4 ó 6 recipientes de barro, estaño u hojalata, metidos todos en unos sacos de cuero que colgaban a cada lado del animal. Se acostumbraba a cerrar los tarros con una tapa de madera envuelta en un trapo, generalmente sucio, para que ajustara mejor" José PANETTIERI: "Los cuenta propia" en La vida de nuestro pueblo, vol. 4, Bs.As., CEAL, 1985.

44 Cédulas censales, Barracas al Norte y Barracas al Sur. Primer censo municipal de la ciudad de Buenos Aires -1855- y primer censo nacional -1869-, Sala X, AGN.

45 Ver PANETTIERI [48]. La misma opinión en trabajos de Carlos MONCAUT: "Recuerdos del tiempo de antes: Tambos y vascos" en EL DIA, La Plata, 2/3/1958.

46 Ver PANETTIERI [48]
} 
nuaban levados y los vascos se reservaron la lechería"47. Como fuera, en 1895 los cuarteles urbanos de Chascomús albergaban un sólo tambero vasco, fenómeno acorde con la preferencia habitacional euskalduna de esa zona ${ }^{48}$. Pero en cuatro de sus cuarteles rurales $(5$, 6,7 y 9) 43 vascos declararon ser tamberos, mientras que 18 manifestaron ser lecheros.

Cuadro 3 Trabajadores vascos EN Chascomus, 1869/1895

\begin{tabular}{rlrr}
\hline & OCUPACIÓN & 1869 & 1895 \\
\hline 1 & Jornalero & 83 & 128 \\
2 & Peón & 178 & 82 \\
3 & Trabajadores domésticos & 63 & 40 \\
4 & Trabajadores rurales especializados & 115 & 91 \\
5 & Trabajadores urbanos especializados & 84 & 24 \\
6 & Comerciantes e industriales & 58 & 61 \\
7 & Func. y profesionales & - & 6 \\
8 & Empres. ganad. y rent. & 21 & 117 \\
9 & Pequeños empresarios agricolas & 6 & 36 \\
10 & Empleados & 21 & 22 \\
11 & Artesanos independientes & 52 & 8 \\
\hline
\end{tabular}

Fuente: CEDULAS CENSALES, CENSOS NACIONALES DE 1869 Y 1895, AGN.

* Estructura del cuadro y datos totales extraidos de Miguez [3] y "La frontera de Buenos Aires en el s. XIX: Población y mercado de trabajo" en MANDRINI y REGUERA (compil.): Huellas en la tierra, Tandil, IEHS, 1993, p. 191.

Los vasco-franceses sumaban 23 tamberos y 7 lecheros mientras que los vasco-españoles 20 tamberos y 11 lecheros. Treinta y dos de esos tamberos se encontraban organizados familiarmente, y el resto lo hacía sólo o ayudado por peones. La imagen no podía ser más clara. En uno de los cuarteles, donde habitaban 24 familias que sumaban 150 personas, los vascos tamberos, sus esposas e hijos ascendían al número de 46. En los casos de tamberos o lecheros con hijos

47 Cravero y Ferrero [45].

48 Entre ellos, 231 habían elegido —o podido- vivir en el pueblo, mientras que más allá de la última calle transitable, donde empezaban las quintas, vivían 582.

R. I., $1997, \mathrm{n}^{\circ} 210$ 
argentinos, hemos podido detectar que 8 llevaban entre uno y cinco años en el país -y posiblemente en la región-; 6 entre seis y diez años y 9 más de once. Estas cifras parecen indicar que la producción tambera era iniciada luego de un período de asentamiento $-\mathrm{y}$ de ahorro- en la zona. La ayuda de paisanos parece haber sido una de las claves del éxito vasco en esta producción ${ }^{49}$. Pero sin duda debió haber más vascos lecheros o tamberos que los contabilizados; potencialmente, y excluyendo a los peones, alrededor de 230 vascos (empresarios ganaderos, productores agrícolas, trabajadores rurales especializados) pudieron estar ligados - quizás parcialmente - con actividades lácteas. Muchos de los puesteros - que declararon ser peones - seguramente estaban a cargo de esa actividad en las estancias que trabajaban, ya para consumo interno o para comercializar. Se puede pensar que el paisaje productivo y la movilidad cotidiana de los lecheros hacia el pueblo donde se agrupaban a diario debió influenciar decisivamente sobre la memoria de los habitantes y viajeros ocasionales del Chascomús finisecular. El escritor Baldomero Fernández Moreno, que pasó parte de su vida allí, describió magistralmente un espacio de sociabilidad de tamberos vascos de fines de siglo.

\footnotetext{
"Estamos en la típica fonda de Barreneche Mucha boina ceñida, mucha faz colorada, mucho vaso de vino tinto en palo campeche mucha bota ordinaria reciamente arrugada mucho tute del medio y mucho !Que aproveche! Ambiente, como veis, tabernario y tambero. Por la puerta del patio se infla un vaho de chiquero, la petisa y la oveja, la vaquita y la chancha jadeando como fuelles, sudando a goterones, juegan a la pelota dos vasquitos peones Los pelotazos suenan cual tiros en la cancha."
}

¿No concurrían a esa taberna vascos zapateros, panaderos o carpinteros, o incluso inmigrantes de otra nacionalidad? Seguro que sí; pero el poeta retuvo en su memoria aspectos sobresalientes del am-

\footnotetext{
49 Se infiere del agrupamiento zonal (en sólo 4 cuarteles) y las contrataciones casi exclusivas de vascos o descendientes; es notable el hecho de que también haya un par de vascos provenientes (según el lugar de nacimiento de sus hijos) de la localidad de Quilmes (norte de Buenos Aires).
} 
biente. Por esa misma época, Tandil -como Lobería, Necochea y otros- también albergaba vascos que se dedicaban a la fabricación de manteca, quesos y cremas. En los alrededores de la piedra movediza -mientras que en 1869 no hubo ningún caso-, hacia 1895 cuatro vascos declararon ser lecheros y seis queseros ${ }^{50}$. La imagen del lechero vasco, como una mancha de humedad, ocupaba ahora gran parte del corredor sudeste de la provincia ${ }^{51}$. Los casos de vascos que alcanzaron progresos en este ramo - otro elemento importante para la perdurabilidad - son abundantes ${ }^{52}$. La imagen del lechero vasco debió originarse, tímidamente, en los alrededores de la ciudad de Buenos Aires; luego se apuntalaría por la multiplicación de los vascos en el oficio en distintos puntos de la provincia; hacia 1880/900 al norte del río Salado y luego en el sudeste. Si existieron puntos neurálgicos donde se afianzó el estereotipo, Chascomús fue sin dudas uno de ellos.

Creemos, llegados hasta aquí -y adelantando conclusiones de una investigación más amplia que excedería este espacio-, que cuando se rastrea en las fuentes un estereotipo laboral aislado (por ejemplo lechero, zanjeador u hornero), raramente se constatan - dentro del universo vasco - situaciones de predominio local ${ }^{53}$. Dos casos atípicos parecen ser los pastores y los peones de saladeros ${ }^{54}$, con producciones 'concentradas' temporal y regionalmente. Ambas actividades demandaban - al menos durante las estaciones de mayor trabajodedicación full time, lo que nos ha permitido constatar cifras nítidas de trabajadores vascos en ellos. No ocurría lo mismo con los lecheros, zanjeadores, carreros y alambradores que complementaban su tiempo con otras tareas, más estables y por tanto frecuentemente

50 Cédulas censales, primer censo nacional (1869) y segundo censo nacional (1895), Sala X, AGN.

51 En 1909, sobre 18 fábricas importantes de estos productos, 8 estaban en manos de vascos (4 cremerías y 4 queserías) Primera guia rural del partido de tandil, Tandil, 1909.

52 Como José Begnatborde, quien llegó en 1856 y luego de estar ocupado durante 6 meses en el cuidado de hacienda se volcó a la tarea de lechero en la capital. En ese trabajo permaneció 17 años y ya con un capital importante se trasladó a San Vicente, donde siguió explotando la riqueza tambera hasta que en 1889 se trasladó a Chascomús donde arrendó varios campos que atendió personalmente. URIARTE [8].

53 Al menos como ocupaciones principales, dado que no han sido declaradas masivamente al censista por los vascos.

54 Mientras que en Barracas al Norte encontramos 18 peones vascos de barracas y 19 peones de saladeros en 1855 y 94 peones de saladero en 1869; en Barracas al Sud, en la segunda fecha, había 124 peones vascos en los saladeros. Primer censo municipal de la ciudad de Buenos Aires (1855) y Primer censo nacional (1869), AGN. 
declaradas como oficio. También podemos adelantar que, tal nuestra hipótesis, estos oficios reunían distintas características que los diferenciaban del resto, principalmente cuando eran llevados a cabo por vascos. Queda claro también que la nitidez y la amplitud geográfica del reconocimiento de una imagen laboral estuvo también ligada a la frecuencia con que los euskaldunes se empleaban en ellos. De allí que la gente no dude en enumerar las imágenes a partir de actividades ampliamente dispersas como las de lechero, pocero, alambrador o ladrillero y con menos certeza las de pastores o peones de saladeros, más acotadas geográficamente. Lo mismo debió suceder con los vendedores turcos, los comerciantes gallegos o los 'golondrinas' y quinteros italianos.

Pero cuando la sensación laboral sobre un grupo inmigratorio no gira alrededor de un oficio sino de una tendencia mayor (caso de los vascos ganaderos en el sudeste bonaerense, Tandil o Lobería) resulta más fácil de comprender. Imágenes de cabañeros, tamberos y pastores se veían reforzadas por oficios rurales ligados fuertemente a ellas como poceros, alambradores, esquiladores e inclusive almacenes de ramos generales. La llegada tardía de la agricultura a esta zona debió tener mucho que ver en ello.

Los vascos se presentan como un grupo nacional asociado a un número considerable de oficios; ésto habla de su dispersión y de la continuidad del flujo inmigratorio a lo largo de distintos períodos y coyunturas. Probablemente también de su adaptabilidad y oportunismo para emplearse. Si le sumamos la importancia relativa de las actividades emprendidas y el simbolismo que solía acompañarlas (vestimenta, deportes, costumbres) es comprensible que se convirtieran en blanco fácil de los viajeros; síntesis didáctica de una época; ejemplo a seguir en los discursos presidenciales; recuerdo pintoresco, a veces heroico en la memoria de nuestros abuelos...

No quisiéramos cerrar éstas páginas sin expresar - sintéticamente - nuestra creencia de que el tema en cuestión pudiera resultar de utilidad para analizar experiencias de integración social. Lo que buscamos recuperar es, en cierta forma, la manera en que el resto de la sociedad - nativos y otros inmigrantes - visualizaba a un grupo nacional. Pudo servir, tal como lo sospecho, en la conformación o apuntalamiento de una imagen de comunidad vasca que se sustenta- 
ba (a falta de instituciones propias ${ }^{55}$ ) básicamente en elementos simbólicos y folklóricos. Esto reforzaría nuestra idea de que una imagen de colectividad nítida, como es el caso de la vasca, no implicaba necesariamente mecanismos 'endogámicos' o institucionales que pudieran convertirse en obstáculos para la integración. Si esto es así, estaremos incorporando al análisis variables 'poco medibles' - si lo comparamos con los casamientos o registros societarios- pero que debieron jugar un papel importante en las experiencias de integración. ¿Acaso podemos ignorar el peso que debió tener el trato cotidiano (laboral) con el resto de la sociedad? Podemos pensar, siguiendo el mismo razonamiento, que los oficios predominantes en un grupo nacional pudieron actuar como aceleradores de la integración o - por el contrario- como un obstáculo. No puedo evitar, al plantear ésto, comparar al lechero vasco con el agricultor danés o el aislado pastor irlandés. Es probable que no experimentaran igual integración -al menos en ámbitos acotados-, los grupos que contaran con oficios 'más sociales' —o urbanos-, con movilidad espacial y clientela diaria que aquellos cuyas características sobresalientes fueran el aislamiento y la propensión a pocos contactos con intermediarios y clientes. ¿Por qué no pensar que estos últimos favorecerían las actitudes endogámicas? Sin embargo, pese a que los oficios ‘ambulantes' como el lechero pudieron acelerar la integración, también debieron servir (a la manera del padre Fahy entre los irlandeses ${ }^{56}$ ) como conectores dentro de la comunidad; por ejemplo aportando datos al mercado laboral o matrimonial, brindando referencias sobre nuevos vascos instalados en la zona, etcétera. El problema queda, dado que excede los límites de este artículo, presentado.

\section{CONCLUSIONES}

Entre 1820 y 1900 Argentina ensayó diversos mecanismos para incorporarse a la economía mundial. La llegada de los inmigrantes, entre los que se encontraban — desde 1840 - los vascos, fue un factor preponderante. A través de numerosas fuentes, aquel aporte

\footnotetext{
55 Los vascos participaron en las Sociedades de Socorros Mútuos Española y en menor medida, Francesa. Los Centros Vascos, salvo excepciones, son más tardíos.

56 Ver Korol y SABATO [4].
}

R. I., 1997, n. $^{\circ} 210$ 
humano ha llegado hasta nuestros días para formar parte - por medio de un número limitado de imágenes- de la memoria popular. Varios elementos pesaron en la consolidación 'histórica' de ciertos oficios 'monopolizados' por los inmigrantes. Los vascos lecheros; los labradores daneses; los 'tanos' mercachifles ó quinteros; los 'gallegos' comerciantes y los 'turcos' vendedores son algunas de aquellas asociaciones que el paso del tiempo consolidó.

Estudiado el caso vasco, la frecuencia con que escogían las labores que el recuerdo les asigna aparece como un elemento principal, pero no único; la importancia coyuntural de algunas actividades e incluso simbolismos culturales que las acompañaban (juego de pelota, vestimenta, costumbres), las que atrajeron la mirada de los 'formadores' del recuerdo. La necesidad de síntesis por parte de instituciones, publicaciones, obras para cine y teatro y discursos presidenciales también aportaron lo suyo en la fijación de aquellas imágenes. Tal como concluye Bestene en su estudio sobre la imagen de los turcos en el teatro argentino, las obras se inspiraron en los estereotipos que surgen de las crencias populares, las que a su vez se alimentan de los estereotipos creados por la élite o la literatura ${ }^{57}$. La sociedad receptora en su conjunto fue, en definitiva, la que ligó asociaciones laborales a los inmigrantes que podían beneficiar u opacar el aporte de sus colectividades al país; en este sentido fue especialmente benévola con los vascos.

La memoria de nuestros abuelos se parece al relato de una buena película pasado un largo tiempo de haber sido vista. Hay cierta confusión en cuanto a los distintos momentos del desarrollo y es probable que no se recuerde algún actor de reparto; pero es difícil que alguien olvide a los protagonistas principales.

The author analyzes the emergence and persistence of images and stereotypes in the nineteenth century Argentine popular culture of certain occupations as typically Basque ones (e.i. the Basque milkman). The emergence of those stereotypes did not necessarily have to do with an overwhelming Basque presence in those occupations but mostly with their features and symbolic implications. For undertaking the analysis the author has mainly used the returns from the Argentine National Censuses of Population from nineteenth century.

57 Ver BESTENE [2], p. 162.

R. I., $1997, \mathrm{n}^{\circ} 210$ 